\title{
ТРАНСФОРМАЦІЯ ЗМІСТУ ПРОФЕСІЙНОЇ ПІДГОТОВКИ МАЙБУТНЬОГО ВЧИТЕЛЯ МУЗИКИ ПОЧАТКОВОЇ ШКОЛИ В КОНТЕКСТІ РЕФОРМИ НОВОЇ УКРАЇНСЬКОЇ ШКОЛИ
}

\author{
Наталя Дермельова \\ старший викладач кафедри музики і хореографії \\ ДВНЗ «Донбаський державний педагогічний університет» \\ м. Слов'янськ, Україна \\ ORCID ID 0000-0001-8368-533X \\ natadermeleva@gmail.com \\ Ольга Ночовка \\ старший викладач кафедри музики і хореографії \\ ДВНЗ «Донбаський державний педагогічний університет» \\ м. Слов'янськ, Україна \\ ORCID ID 0000-0002-8296-3227 \\ nochovkaolha@gmail.com
}

\begin{abstract}
Анотація. У статті обгрунтовано важливість оновлення змісту професійної підготовки майбутнього вчителя музики початкової школи, що зумовлено імплементацією реформи Нової української школи, а також новими стандартами початкової та вищої освіти. Під час дослідження чинників, що впливають на трансформацію навчального контенту, авторки спираються на потужну теоретичну і нормативно-правову базу. У статті зроблено висновок, що ключовими аспектами оновлення змісту професійної підготовки майбутнього вчителя музики початкової школи мають стати діяльнісна спрямованість процесу підготовки, чітке структурування вимог до навчальних досягнень студентів, орієнтація на дотримання інтегративного підходу через узгодження програмового змісту предметів мистецької освітньої галузі із змістом інших освітніх галузей, готовність застосування формувального й вербального оцінювання тощо. Ці аспекти дозволили авторкам указати на необхідність перегляду і трансформації змісту професійної підготовки майбутнього вчителя музики початкової школи на бакалаврському рівні вищої освіти.
\end{abstract}

Ключові слова: професійна підготовка; майбутній учитель музики початкової школи; компетентнісний підхід; інтегративний підхід; педагогічне проектування.

Постановка проблеми в загальному вигляді. Актуальність готовності людини до змін визначається реаліями життя, які потребують посилення духовного начала на противагу поширенню проявів антилюдяності, антигуманності. У цьому контексті соціокультурні процеси неминуче детермінують переосмислення концептуальних засад мистецької освіти i відповідно - стратегій іiі вибудовування. Мистецька освіта, крім того, що продовжує виконувати притаманне їй завдання художнього та загальноестетичного розвитку особистості, значною мірою акцентує свою 
значущість у формуванні іï як творця культури життя загалом, у всіх сферах, що якнайкраще сприяє самопізнанню, необхідному сучасній людині в іiї пошуках духовності.

Основне навантаження покладено на загальну мистецьку освіту, тобто ту ланку системи, яка охоплює все суспільство, бо є обов'язковою для всіх дітей: учнів загальноосвітніх навчальних закладів, що занурені в багатоскладовий художньо-освітній простір - уроки мистецьких дисциплін у школі та позаурочне життя, підпорядковані педагогічному керуванню 3 його специфічними завданнями, а також відчувають і гостро та інколи непередбачувано реагують на впливи потужних стихійних інформаційних потоків. Отже, учитель (і не лише мистецтва) має усвідомити об'єктивність піднесення ролі мистецької освіти, кінцевою метою якої $\epsilon$ здатна творити себе особистість, оптимально використовуючи ії потенціал у різних сферах знання.

Особливої актуальності набуває проблема підготовки вчителів початкової школи, адже їхні компетентності, якості, що формуються в умовах навчання у вищій школі, зокрема динамізм, креативність, конструктивність, комунікативність стимулюватимуть становлення життєво необхідних якостей особистості молодшого школяра i $\epsilon$ підгрунтям подальшого успішного ступеневого шкільного навчання. Реформування професійної підготовки майбутніх учителів початкової школи в Україні є частиною процесів оновлення освітніх систем. Ці зміни стосуються створення нових стандартів вищої освіти, оновлення та перегляду навчальних програм, змісту навчально-дидактичних матеріалів, підручників, форм, методів і технологій навчання. Цілеспрямоване набуття студентською молоддю знань, умінь і навичок у галузі педагогічної освіти, їхня трансформація в компетентності сприяє особистісному культурному зростанню, розвитку освітніх технологій, здатності швидко реагувати на запити часу. Саме тому важливим $є$ усвідомлення поняття компетентності в суспільстві, що базується на знаннях, уміннях, досвіді, моделях поведінки. Важливо розуміти яких саме компетентностей необхідно набути фахівцеві і яким повинен бути результат професійної підготовки.

Аналіз останніх досліджень і публікацій. Закон України «Про освіту», Національна доктрина розвитку освіти пропагують особистісний розвиток учителя як найвищу цінність суспільства. Цій проблемі присвячені наукові дослідження в галузі філософії освіти (В. Андрущенко, Б. Гершунський, I. Зязюн, В. Кремень); професійної підготовки фахівців у вищій школі (А. Алексюк, С. Гамараш, С. Гончаренко, А. Гуржій, А. Капська, В. Козаков, М. Лазарєв, П. Підкасистий, В. Семиченко, С. Сисоєва); теорії компетентнісного підходу до навчання (В. Байденко, Є. Зеєр, І. Зязюн, Л. Мітіна, О. Овчарук, О. Пометун). Особливості професійної та педагогічної освіти вивчаються В. Бехом, О. Бідою, Г. Васяновичем, О. Дубасенюк, В. Свтухом, І. Зязюном, С. Лісовою, Н. Ничкало, А. Нісімчуком, Л. Онищук, Г. Яворською. Світоглядні й суто методичні аспекти мистецької освіти та педагогіки мистецтва висвітлено 
в дослідженнях визначних науковців: С. Горбенко, А. Козир, Л. Лимаренко, Л. Масол, Н. Миропольської, О. Олексюк, Г. Падалки, О. Ребрової, Т. Смирнової, О. Щолокової).

Метою статті $\epsilon$ аналіз принципових змін, які мають відбутися в професійній підготовці майбутнього вчителя музики початкової школи та які зумовлені впровадженням Концепції Нової української школи.

Результати дослідження. Зміни, на які очікує суспільство, зокрема й від мистецької освітньої галузі, зафіксовано в низці документів проекту «Нова українська школа» (Державний стандарт; Закон України про освіту; Концепція НУШ), стрижневою ідеєю якого є реалізація іï компетентнісного потенціалу у векторах формування комплексу ключових життєвих компетентностей, зокрема і в професійно-педагогічній підготовці.

Професійно-педагогічна підготовка розглядається вченою О. Хижною (2007) як підготовка майбутнього вчителя до неперервного професійного розвитку, процес привласнення знань, умінь, навичок, способів дій у системі професійної освіти, необхідних для здійснення того або того виду професійної діяльності (с. 46). Будучи за своєю суттю культуротворчою, художньопедагогічна діяльність в різні періоди розвитку суспільства відображала та відображає певний рівень культури. Художньо-педагогічна підготовка розглядається в цьому контексті як важливий механізм культурної спадкоємності, форма збереження і розвитку культурного надбання нації і всього людства, фактор життєздатності молодого покоління, яке завтра буде визначати долю України як важливий ресурс духовного відродження і стратегічний напрям державної політики; і зумовлює ііі визначення як процес і результат педагогічно організованого становлення особистості студента як суб'єкта культури та освіти шляхом освоєння системи художньо-педагогічних знань, цінностей, принципів комунікації та досвіду художньо-педагогічних практик.

Згідно з сучасними науковими підходами і запитами педагогічної практики підготовку майбутніх учителів до забезпечення основ мистецької освіти учнів початкової школи визначаємо як розгорнутий у часі об'єктивний процес, що має свою мету, закономірності, відповідну структурно-функціональну побудову, центровану навколо інтегративних видів художньо-педагогічної діяльності, що забезпечує залучення до культурно детермінованих шляхів вирішення завдань особистісної та професійної життєдіяльності та створює умови для самовизначення майбутнім фахівцем основних параметрів готовності до художньо-педагогічної діяльності та культури художньо-педагогічної діяльності i водночас як результат, що фіксується в кожний момент цього процесу: конкретний образ конкретного вчителя, але не статичний, а в динаміці розвитку.

Мета підготовки студентів до забезпечення мистецької освіти учнів початкової школи полягає у формуванні готовності майбутніх фахівців до здійснення процесу художньо-естетичного виховання молодших школярів, формуванні особистісних і суспільно значущих світоглядних якостей фахівців, 
індивідуального визначення у світі мистецьких цінностей, а також активізації процесів професійного вдосконалення на шляху мистецької самореалізації, саморозвитку та самовдосконалення особистості.

2018 - 2019 навчальний рік є стартом для Нової української школи в початковій ланці загальної середньої освіти та продовженням реалізації концептуальних ідей НУШ у загальній мистецькій освіті основної та старшої школи. Предмети художньо-естетичного циклу в школі спрямовані на розвиток емоційно-чуттєвої сфери учнів, формування їхнього художньо-образного, асоціативного, критичного мислення; створення сприятливих умов для продукування креативних ідей, реалізацію власних творчих потреб у художній діяльності та пізнанні. Водночас через образний зміст творів мистецтва, відкриваються широкі можливості ефективно впливати на формування патріотизму, моралі та інших загальнолюдських цінностей.

Реалізація зазначеної мети передбачає виконання комплексу завдань, серед яких виокремлюємо: формування цілісної системи художньо-педагогічних знань; формування ціннісних орієнтацій, художньо-педагогічних умінь i навичок, професійної самосвідомості, яка базуватиметься на основі опанування досвіду художньо-творчої діяльності майбутніх учителів, орієнтованої на забезпечення продуктивного входження в соціокультурну та освітню практику; відкритості до художньо-педагогічних інновацій; формування досвіду культуротворчої діяльності; засвоєння суб'єктної природи культурних процесів як інструмента гуманізації стратегій професійної діяльності.

Розв'язання проблеми якості освіти передбачає достатньо радикальну зміну стандартів вищої освіти в галузі підготовки майбутніх учителів початкових класів. Проблема стандартів вищої освіти досліджується 3 соціальнопедагогічного, філософського погляду і набуває дедалі більшої актуальності, адже це повсякчасне збалансовування таких трьох вимог: збереження i примноження національних освітніх традицій; підпорядкування суспільним, економічним, політичним законам сьогодення в контексті розвитку світових освітніх систем; здатність або спроба забезпечувати рух на випередження, інноваційність (Волошко, 2005).

Формування професійної компетентності закладено в змісті освітньопрофесійної програми спеціальності «Початкова освіта» як складової стандарту вищої освіти. Цей процес включає оволодіння: змістовим і процесуальним компонентами педагогічної діяльності, знаннями логіки навчальних дисциплін; уміннями оперувати категоріями діалектики та основними поняттями, які утворюють концептуальний каркас педагогічної науки, перетворювати педагогічні теорії в метод пізнавальної діяльності; навички самоосвіти та підвищення рівня кваліфікації, ділового, міжособистісного та педагогічного спілкування (Онищенко, 2012).

Щодо предмета нашого дослідження: формування мистецької освітньої компетентності майбутніх учителів початкових класів, то аналіз стандартів у 
частині мистецько-освітньої підготовки вчителя початкової школи в Україні показав, що вони орієнтують на вибудовування діяльнісного аспекту процесу підготовки. Студенти повинні відкривати нові знання; самостійно засвоювати готові мистецькі знання; розуміти внутрішні та міжпредметні зв'язки, оволодівати методологією мистецької освіти; розуміти функціонування процесу навчання (яке полягає в тому, що кожен окремий учень не копіює знання вчителя, а створює власну картину мистецьких цінностей, яка залежить від особливостей сприйняття та переробки інформації); знати психічні особливості, закономірності процесу засвоєння знань учнів, ознайомитися 3 питаннями психології оволодіння мистецькими знаннями.

Однак у пояснювальній записці до програми курсу «Методика вивчення освітньої галузі «Мистецтво» вказується на необхідність формування в студентів професійних умінь щодо організації та здійснення навчально-творчої діяльності молодшого школяра. У змісті навчальної дисципліни виокремлюється робота із завданнями творчого і розвивального характеру, передбачається навчання студентів самостійно розв'язувати такі завдання, усвідомлення студентами можливості їхнього використання на уроках із навчальних дисциплін «Образотворче мистецтво», «Музика» та інтегрованого курсу «Мистецтво». Проте роботу над такими завданнями розвивального характеру на уроках художньо-естетичного циклу пропонується майбутньому вчителеві здійснювати локально: на практичних заняттях у вигляді тренування. Якість вищої мистецької освіти визначається сукупністю показників, які характеризують різні аспекти навчальної діяльності освітньої установи: зміст освіти, форми й методи навчання, матеріально-технічна база, кадровий склад тощо та забезпечують розвиток компетенції тих, хто навчається. Викладачі вищих навчальних закладів, добираючи діагностичні завдання, які передбачають вивчення рівня сформованості компетентності майбутнього вчителя 3 методики викладання освітньої галузі «Мистецтво» в початковій школі, мають ураховувати, що оновлення змісту мистецької підготовки на засадах компетентнісного підходу спрямовується на чітке структурування вимог до навчальних досягнень студентів (наприклад: знає, усвідомлює, визначає, розуміє, застосовує, володіє).

Зміст мистецької освітньої галузі в 1-х класах може реалізовуватися як через інтегрований курс «Мистецтво», так і через окремі предмети за видами мистецтва: образотворче мистецтво і музичне мистецтво. Вибір здійснюється 3 урахуванням фахової підготовки кадрового складу педагогічних працівників школи та погоджується педагогічною радою. Якщо школою для вивчення обрано другий варіант, то в робочому навчальному плані зазначаються окремі навчальні предмети: «Мистецтво: образотворче мистецтво», «Мистецтво: музичне мистецтво», на які відводиться по 1 годині на тиждень. Необхідною умовою реалізації завдань освітньої галузі «Мистецтво» $є$ дотримання інтегративного підходу через узгодження програмового змісту предметів мистецької освітньої 
галузі із змістом інших освітніх галузей (наприклад, сприймання музичного твору, мультфільму тощо на заняттях із вивчення мови).

При цьому варто зауважити, що в процесі інтеграції кількість навчальних годин, передбачених на вивчення мистецької освітньої галузі, перерозподіляється без зменшення їхнього сумарного значення (2 години на тиждень). Використання навчальних посібників, зошитів із друкованою основою, що доповнюють зміст підручників та утворюють разом із ними навчальні комплекти, є необов'язковим і може мати місце в освітньому процесі лише за умови дидактичної доцільності навчальних видань для реалізації нових підходів у роботі з учнями, дотримання вимог щодо уникнення перевантаження учнів та добровільної згоди всіх батьків учнів класу на фінансове забезпечення.

Новий Державний стандарт початкової освіти (затверджений постановою Кабінету Міністрів України № 87 від 21.02.2018 (чинний у 1 класах), регламентуючи свободу педагогічних спільнот у виборі шляхів навчання, виховання і розвитку школярів, відкриває можливість вибору та створення власного навчального забезпечення освітнього процесу. Чинні вимоги до його якості доповнюються показниками, що відповідають пріоритетам нового Державного стандарту і передбачають: реалізацію ідеї інтеграції; дослідницький підхід до формування вмінь; конструювання знань, а не їхнє відтворення; організацію пошуку інформації з різних джерел; розвиток критичного мислення, творчості тощо.

3 першого дня спілкування дітей із мистецтвом у школі слід спрямовувати їх на уважне слухання і споглядання творів мистецтва, виявлення власних вражень, пошук змісту та розуміння, яким чином він розкривається. Учнів потрібно системно і послідовно привчати визначати, описувати емоційні стани, викликані почутим, побаченим, формувати культуру емоційного сприймання й реагування на твір мистецтва. Упродовж навчання в початковій школі в дітей мають системно формуватися виконавські вміння та навички, характерні для кожного окремого виду художньої діяльності: графічні, живописні, декоративні техніки, знайомство з правилами композиції, кольорознавства, ліплення тощо (3 образотворчого мистецтва); уміння сприймати твори мистецтва та висловлювати ставлення до них, вокальні та хорові навички (з музичного мистецтва); акторські та елементарні хореографічні вміння під час театралізацій, інсценізацій, рольових ігор і рухів під музику.

Водночас у контексті інтегрованого навчання відбувається формування поліхудожніх умінь: порівняння засобів виразності в різних видах мистецтва, відтворення різних явищ через музичні інтонації, малюнок, рух, жест, слово; пошук звукових асоціацій у творах образотворчого мистецтва; «оживлення» творів образотворчого мистецтва, програмної музики за допомогою пантоміми, міміки, жестів, рухів або розігрування уявних діалогів за сюжетом картини; створення ілюстрацій до казок, мелодій до віршів, інсценізація пісні тощо. Велике значення для розвитку творчості дітей має активне залучення до 
імпровізацій, різного роду експериментів (наприклад, з кольорами, звуками), а також підтримка їхніх ідей та ініціатив у прикрашанні, естетизації навколишнього середовища, що значно розширює можливості дітей у власному художньо-творчому самовираженні. Окрім того, важливо привчати дітей не лише творити і самовиражатися, але й презентувати результати власної творчості, брати участь у шкільних мистецьких заходах (концертах, виставках, інсценізаціях тощо), а з часом виявляти ініціативу їхнього створення, спілкуватися з друзями та знайомими про мистецтво.

На основі навчальної програми предмета/інтегрованого курсу вчитель складає календарно-тематичне планування в довільній, зручній для використання формі 3 урахуванням навчальних можливостей учнів класу. Можливе використання друкованих чи електронних джерел тощо. Формат, обсяг, структура, зміст та оформлення календарних планів і поурочних планівконспектів $\epsilon$ індивідуальною справою вчителя. Встановлення універсальних у межах закладу загальної середньої освіти міста, району чи області стандартів таких документів є неприпустимим. Автономія вчителя має бути забезпечена академічною свободою, включаючи свободу викладання, свободу від втручання в педагогічну, науково-педагогічну та наукову діяльність, вільним вибором форм, методів і засобів навчання, що відповідають освітній програмі, розробленням i впровадженням авторських навчальних програм, проєктів, освітніх методик i технологій, методів i засобів, насамперед методик компетентнісного навчання. Учитель має право самостійно переносити теми уроків відповідно до засвоєння учнями навчального матеріалу, визначати кількість годин на вивчення окремих тем. Адміністрація закладу загальної середньої освіти або працівники методичних служб можуть лише надавати методичну допомогу вчителю 3 метою покращення освітнього процесу, а не контролювати його.

У типових освітніх програмах початкової освіти підкреслено необхідність застосування формувального й вербального оцінювання. Ці види оцінювання змінюють функції вчителя в процесі контролю й оцінювання навчальних досягнень учнів, натомість діти поступово у співпраці 3 педагогом мають оволодівати вміннями самооцінки й самоконтролю, тобто ставати суб'єктами учіння. Концепцією Нової української школи та Державним стандартом початкової освіти передбачено, що в шкільному житті зросте частка групової ігрової, проектної і дослідницької діяльності, мають бути урізноманітнені варіанти впорядкування освітнього середовища (Державний стандарт; Концепція НУШ). Крім класичних варіантів класних кімнат, доцільно використовувати мобільні робочі місця, які можна легко трансформувати для групової роботи. У плануванні і дизайні освітнього середовища першорядним має бути спрямування на розвиток дитини і мотивації іiі до навчання.

В освітньому середовищі Нової української школи існує баланс між навчальними видами діяльності, ініційованим учителем і видами діяльності, 
ініційованими самими дітьми. Таке середовище забезпечує можливості дітям робити власний вибір, можливості для розвитку нових та вдосконалення наявних практичних навичок, отримання нових знань, розвитку свого позитивного ставлення до інших. Для того щоб освітне середовище заохочувало дітей до самовизначення і сприяло розвитку їхніх спроможностей, необхідно, щоб воно було мобільним, легко трансформувалося для колективної, групової роботи (Митник, 2008). Крім того, усі навчальні об'єкти, якими безпечно можуть користуватись учні, мають бути доступними дитині, щоб вона мала можливість вільно пересуватися класом для пошуку необхідних навчальних матеріалів. Це забезпечуватиме можливості здійснювати вибір у класі i, відповідно, приймати самостійні рішення щодо навчальної діяльності, усвідомлюючи при цьому наслідки вибору.

Педагогічне проектування дасть змогу забезпечити перехід наявного стану професійної підготовки майбутнього вчителя музики початкових класів на якісно новий рівень, оптимізувати його зміст, організацію і керування ним. Водночас здійснення проектування освітнього середовища професійної підготовки майбутнього вчителя потребує врахування особливостей мистецькоосвітньої діяльності в Україні, має базуватися на цінностях професійної діяльності, інноваційних технологіях підготовки відповідно до вітчизняних $\mathrm{i}$ світових стандартів, тенденцій інтеграції у світовий освітній простір, повинно мати випереджувальний характер.

Створення інноваційного художньо-педагогічного освітнього середовища, спрямованого на забезпечення самореалізації особистості майбутнього вчителя початкової школи в галузі мистецької освіти та заснованого на розробці та застосуванні в навчальному процесі інтенсивних, інтерактивних та інформаційно-комунікаційних форм і методів задоволення його професійноосвітніх та художньо-творчих потреб. Проектоване нами інноваційне художньопедагогічне освітнє середовище характеризується такими ознаками: наявність настанов i позитивної мотивації на художньо-педагогічну діяльність майбутнього вчителя початкової школи; здійснення цілеспрямованої, систематичної підготовки студентів до опанування знаннями 3 психологопедагогічних i професійно орієнтованих дисциплін художньо-педагогічного спрямування та формування індивідуально-творчого стилю професійнопедагогічної діяльності; наявність емоційно сприятливого клімату та взаємостосунків співпраці і співтворчості, діалогового спілкування між викладачами i студентами в процесі професійної підготовки; створення атмосфери культурно-освітнього середовища, наповненого художньо мистецьким змістом.

Висновки. Отже, формування професійної компетентності майбутнього вчителя початкових класів у галузі мистецької освіти представляє собою цілісний безперервний процес, який реалізується в умовах освітнього середовища професійної підготовки цих фахівців. Технологія проектування 
освітнього середовища професійної підготовки педагогів передбачає єдність, взаємозумовленість, наступність усіх функцій і структурних компонентів, що іiі формують. Ї̈ї неперервність є необхідною умовою розширення і поглиблення професійної підготовки, забезпечення можливості постійного переходу фахівця на новий, вищий рівень фахової компетентності.

\title{
СПИСОК ВИКОРИСТАНИХ ДЖЕРЕЛ
}

1. Волошко, Л. Б. (2005). Професійна компетентність студентів як предмет психологопедагогічного аналізу. Наука і сучасність, 48, 22-32.

2. Державний стандарт початкової освіти. №87. (2018, 21 лютого). URL: https://www.kmu.gov.ua/ua/npas/prozatverdzhennya-derzhavnogo-standartu-pochatkovoyi-osviti

3. Закон України про освіту. №2145-19. (2017, 5 вересня). URL : http://zakon2.rada.gov.ua/laws/show/2145-19

4. Концепція «Нова українська школа. (2016, 27 жовтня). URL: https://mon.gov.ua/storage/app/media/zagalna\%20serednya/novaukrainska-shkola-compressed.pdf

5. Митник О. (2008). Розвиток професійної компетентності сучасного вчителя: реалії і перспективи. Початкова школа, 7, 35-37.

6. Онищенко, I. (2012). Модель формування фахової компетентності майбутнього вчителя початкових класів. Навчання $і$ виховання обдарованої особистості: теорія та практика, 8, 94-101.

7. Пометун, О. (2005). Компетентнісний підхід - найважливіший орієнтир розвитку сучасної освіти. Рідна школа, 1, 65-69.

8. Хижна, О. П. (2007). Художньо-педагогічна діяльність учителя початкової школи (теоретико-методологічний та методичний аспекти). Київ, Україна: Вид-во НПУ імені М. П. Драгоманова.

\section{TRANSFORMATION OF THE CONTENT OF FUTURE PRIMARY SCHOOL MUSIC TEACHER PROFESSIONAL TRAINING IN THE CONTEXT OF THE NEW UKRAINIAN SCHOOL REFORM}

\author{
Natalia Dermelova \\ Senior Lecturer of the Department of Music and Choreography \\ SHEI "Donbas State Pedagogical University" \\ Sloviansk, Ukraine \\ ORCID ID 0000-0001-8368-533X \\ natadermeleva@gmail.com \\ Olha Nochovka \\ Senior Lecturer of the Department of Music and Choreography \\ SHEI "Donbas State Pedagogical University" \\ Sloviansk, Ukraine \\ ORCID ID 0000-0002-8296-3227 \\ nochovkaolha@gmail.com
}




\begin{abstract}
The article substantiates the importance of updating the content of the professional training of future primary school music teacher as a result of the implementation of the New Ukrainian School reform, as well as new standards for primary and higher education. These changes concern creating of new standards for higher education, updating and reviewing curricula, content of teaching materials, textbooks, forms, methods, and teaching technologies. In the study, the factors influencing the transformation of educational content are revealed. The authors rely on a powerful theoretical and law resources.

The authors of the article come to the conclusion that the key aspects of updating the content of the professional training of the future primary school music teacher should be the activity-based training process, the clear structuring of the requirements for students' academic achievements, the orientation towards adherence to the integrative approach through the coordination of the program content of the subjects of the artistic and educational branch with the content of other educational branches, and readiness for using verbal assessment, etc.

The special attention is paid to pedagogical designing which allows to prove that the current state of professional training of future primary school music teachers is transferred to the new level, to optimize its content, organize, and manage it. Designing the educational environment for the future teacher professional training, it is necessary to take into account the peculiarities of artistic education in Ukraine. It should be based on the values of professional activity, innovative training technologies in accordance with national and world standards, trends of integration into the world educational space, as well as it should have a proactive character. These aspects have allowed the authors to point out the need to revise and transform the content of the professional training of future primary school music teachers at the Bachelor level of higher education.
\end{abstract}

Key words: professional training; future primary school music teacher; competence-based approach; integrative approach; pedagogical designing.

\title{
REFERENCES
}

1. Voloshko, L. B. (2005). Students' professional competence as a subject of psychological and pedagogical analysis. Nauka i suchasnist, 48, 22-32.

2. State Standard of Primary Secondary Education. №87. (2018, February 21). Retrieved from: https://www.kmu.gov.ua/ru/npas/prozatverdzhennya-derzhavnogo-standartu-pochatkovoyiosviti

3. Law of Ukraine on education. № 2145-19. (2017, September 5). Retrieved from: http://zakon2.rada.gov.ua/laws/show/2145-19

4. Concept "New Ukrainian school". (2016, October 27). Retrieved from: https://mon.gov.ua/storage/app/media/zagalna\%20serednya/novaukrainska-shkola-compressed.pdf

5. Mytnyk, O. (2008). Development of professional competence of a modern teacher: realities and perspectives. Pochatkova shkola, 7, 35-37.

6. Onyshchenko, I. (2012). The model for forming the professional competence of the future primary school teacher. Navchannia I vykhovannia obdarovanoi osobystosti: teoriia ta praktyka, 8 , 94-101.

7. Pometun, O. (2005). Competency approach - the most important benchmark for the development of modern education. Ridna shkola , 1, 65-69.

8. Khyzhna, O.P. (2007). Artistic and pedagogical activity of the primary school teacher (theoretical and methodological aspects). Kyiv, Ukraine: Vyd-vo NPU imeni M. P. Dragomanova.

Матеріали надійшли до редакції 07.05.2019 р. 